IZA DP No. 6546

The Impact of the 1996 US Immigration Policy Reform (IIRIRA) on Mexican Migrants' Remittances

Matias I. Vaira-Lucero

Daehoon Nahm

Massimiliano Tani

May 2012 


\title{
The Impact of the 1996 US Immigration Policy Reform (IIRIRA) on Mexican Migrants' Remittances
}

\author{
Matias I. Vaira-Lucero \\ Macquarie University \\ Daehoon Nahm \\ Macquarie University \\ Massimiliano Tani \\ Macquarie University \\ and IZA
}

Discussion Paper No. 6546

May 2012

IZA

P.O. Box 7240

53072 Bonn

Germany

Phone: +49-228-3894-0

Fax: +49-228-3894-180

E-mail: iza@iza.org

\begin{abstract}
Any opinions expressed here are those of the author(s) and not those of IZA. Research published in this series may include views on policy, but the institute itself takes no institutional policy positions.

The Institute for the Study of Labor (IZA) in Bonn is a local and virtual international research center and a place of communication between science, politics and business. IZA is an independent nonprofit organization supported by Deutsche Post Foundation. The center is associated with the University of Bonn and offers a stimulating research environment through its international network, workshops and conferences, data service, project support, research visits and doctoral program. IZA engages in (i) original and internationally competitive research in all fields of labor economics, (ii) development of policy concepts, and (iii) dissemination of research results and concepts to the interested public.
\end{abstract}

IZA Discussion Papers often represent preliminary work and are circulated to encourage discussion. Citation of such a paper should account for its provisional character. A revised version may be available directly from the author. 


\section{ABSTRACT}

\section{The Impact of the 1996 US Immigration Policy Reform (IIRIRA) on Mexican Migrants' Remittances}

This paper investigates the effect of the US Illegal Immigrant Reform and Immigrant Responsibility Act of 1996 (IIRIRA) on the remitting patterns of Mexican immigrants. Using data from the Mexican Migration Project (MMP128), we find that a significant effect on remittance flows from illegal migrants took place after the implementation of the IIRIRA. This is consistent with the hypothesis that illegal immigrants are risk-averse agents who transfer more money to their home country as a mechanism to insure themselves against higher degrees of uncertainty within their host countries. Furthermore, this finding confirms previous research that conditions and policies in the host country affect migrants' remitting behaviour, and migrants' motivations are not only altruistic but also self-interested. Given that migrants' remittances and their savings are important sources of capital formation in many sending countries and of savings in the countries that host them, a better understanding of the effect that migration policies have on remittance flows can lead to more informed policies that can transcend the home security aspects that often dominate discussions about illegal migration.

JEL Classification: F22, F24, J61

Keywords: remittances, legal status, uncertainty, policy reform, illegal migrants, Mexico, migration policy

Corresponding author:

Matias I. Vaira-Lucero

Department of Economics

Macquarie University

NSW 2109

Australia

E-mail: matias.vaira@mq.edu.au 


\section{Introduction}

Unauthorized, or 'irregular', migration is a phenomenon that concerns the general public and policy makers in most countries as it is unregulated, reduces the potential tax receipt in the host country while increasing its expenditure on policing, and raises fears of cut-throat competition for jobs and local public goods for natives. Unauthorized migrants however are not necessarily a synonym for undesirable economic consequences. For some countries, illegal migration may be an effective way to reduce the domestic over-supply of labour. It might fill particular niches of skill shortages in the host countries like home services or generic helpers.

Illegal migrants, like their legal counterparts, also send remittances back to their homeland. By so doing they contribute to raise consumption and investment in sending countries, and their level of economic development. Estimates of the international flow of remittances suggest that in 2010 they were nearly three times the amount of official aid and almost as large as the amount of foreign direct investment (FDI) flows to developing countries (Ratha D., Mohapatra S., and Silwal A., 2011). Many factors affect the occurrence and extent of remittances' flows. These include family and personal characteristics, migrants' motivations to leave their homeland, and changes in socioeconomic conditions in host and home countries that are sometimes caused by policy reforms.

While the literature on migration has increasingly researched the role that remittances play in enhancing development in low-income countries, little is known about the contribution of illegal migration to the supply of remittances. Yet, due to the 'risky' nature of unauthorized migration, illegal migrants are likely to send home a large portion of their income. Perhaps more importantly, the flow of remittances from unauthorized migrants is likely to be highly 
susceptible to changes in the immigration laws in the host country, with flow on effects on the amount of remittances available for consumption and investment in the countries of origin. This paper contributes to the existing literature by analysing the effect of a policy change in the US in the mid-1990s on the remittances of Mexican illegal migrants. Specifically, we will assess whether, if at all, the Illegal Immigrant Reform and Immigrant Responsibility Act (IIRIRA) changed the amount and probability of remitting among illegal Mexican migrants in the USA. As the IIRIRA imposed severe sanctions on illegals it can be seen as a quasi-natural experiment of a more uncertain environment associated to a migrant's legal status.

Since migrants' remittances and savings are important sources of capital formation, a better understanding of what motivates migrants' decisions may lead to migration policies that boost economic development in the sending countries but also enhance the allocation of private and public resources in the host countries. For example, the recognition by the USA government of "matricula consular" as a means to grant access to the banking system to Mexican illegal migrants was one policy motivated by research into their savings and remittance behaviour. This shows that such initiative not only increased migrants' savings in the US, to the advantage of the US banking system, but also increased subsequent remittances to Mexico (Amuedo-Dorantes and Bansak, 2006).

The Mexico-USA migrants' corridor is perhaps one of the best documented for studies of both legal and illegal migration. Mexicans represent a significant proportion of the US immigrants' population (32\% in 2008 according to the Pew Hispanic Center) and their remittances constitute a vital flow of income for the Mexican economy. This paper also complements the results obtained by Amuedo-Dorantes and Mazzolari (2010) about the remitting behaviour of Mexican migrants and their responses to an amnesty program implemented in the US in 1986. 
The rest of the paper is organized as follows. A background of the IIRIRA is introduced in Section 2 followed by a brief literature review focusing on migrants' motivations to send money home and the relationship with income uncertainty in Section 3. A theoretical model explaining migrants' remitting behaviour is discussed in Section 4, while data are presented in Section 5. Section 6 focuses on the empirical strategy and the results are analysed in Section 7. Section 8 draws some conclusions and policy implications

\section{Background of the IIRIRA}

To understand the IIRIRA purpose and the possible effects of its application, we need to clarify briefly the history and evolution of immigration policies in the US. Since the country's founding, immigration has been a subject of legislation for the policymakers, but one of the major changes occurred in 1965 when the amendments to the 1952 Immigration and Nationality Act (INA) abolished the national-origins (ethnic-based) quota system and established a categorical preference system. The new system provided preferences for relatives of U.S. citizens and lawful permanent residents and for immigrants with skills considered useful to the United States.

Since then, the origins of immigrants to the US have shifted from Europe to Latin America and Asia according to the US Immigration and Naturalization Service (INS). This change in the patterns of immigration was also parallel to a change in policy considerations, turning the attention of policy makers to legislation in order to control the entry of illegal migrants as well as the provisions for refugees and refugees-related issues. The result was a new amendment to The Immigration and Nationality Act of 1952 to include the Refugee Act of 1980; furthermore, in response to the growing magnitude of the illegal migration problem, new legislation was considered and passed by the US Congress, enacted as the Immigration Reform and Control Act of 1986 (IRCA). This Reform enhanced enforcement and imposed 
sanctions on employers who knowingly hired or recruited unauthorized aliens. The law also created two amnesty programs for unauthorized immigrants and a new classification for seasonal agricultural workers.

In September 30, 1996 another significant piece of legislation was signed by the US President called Illegal Immigration Reform and Immigrant Responsibility Act (IIRIRA) which focused on the management of illegal immigrants, reforming the entire system of exclusion and deportation. Prior to the passage of IIRIRA, the Immigration and Nationality Act (INA) provided immigration judges with some discretion to grant relief from deportation for longterm migrants who were not legally residing in the U.S. but who had lived there for a long time and had other extenuating circumstances. IIRIRA made this form of relief much more difficult to obtain and completely bars anyone who has been convicted of an aggravated felony from even applying for this type of relief (www.visalaw.com).

In summary, the new reform (IIRIRA) established:

a) Improvements to border control: the reform authorized 5,000 new border patrol agents by 2001 and the INS was allowed to hire 300 additional investigators targeting visa over stayers. Furthermore, a 14-mile-long triple fence at San Diego eastwards was budgeted to be constructed.

b) New provisions against migrants smuggling and document fraud: variations of these types of offenses were added to the list of crimes such as procurement of citizenship or naturalization unlawfully, reproduction of naturalization papers and the sale of those papers.

c) Revamping of the procedures for inspection, removal, detention and deportation of illegal migrants: the reform introduced new penalties for illegal migrants and determined their severity based on the amount of time that a migrant was unlawfully present in the US (over-stayers or entering without inspection). For instance, when could be proved that the 
migrant resided illegally in the US for more than 180 days the penalty was a 3 years bar to legal admissibility, which was raised to 10 years for an illegal stay exceeding one year. The effective date for the applicability of those sanctions was April 1, 1997, and there were no ways for appealing the INS’ decision on a ruling of these new bars.

In addition to those penalties, it was introduced a controversial change in the immigration procedure, which allowed officers from the Immigration and Naturalization Service (INS) to rule unilaterally that a migrant was inadmissible to the US and therefore be removed immediately without any judicial oversight. This expedited procedure applied at migrants arriving at a port of entry or those who were not able to demonstrate that they were continuously present in the US for the two preceding years, with the only exception applying to those who expressed an intention to apply for asylum, based on a "credible fear of persecution” (www.visalaw.com).

These new rules among others from the IIRIRA imposed additional uncertainties on undocumented migrants and may have had a significant effect on their remitting behaviour.

The timing of the IIRIRA coincides with a spike in the proportion of deportations of illegal immigrants in 1997 and 1998 vis-à-vis previous years (Figure 1 in the Appendix).

\section{Literature}

The interest in remittances and their motivations was originally prompted by Lucas and Stark (1985) with an empirical study on Botswana. They found that remittances increase with both migrants' earnings and the households' pre-transfer income, suggesting that migrants not only remit for pure altruistic reasons but also with "self-interest”, what they call "tempered altruism.” The work of Lucas and Stark (1985) has generated further empirical work on migrants' remittances in different contexts, particularly exploring additional explanations beyond altruism. 
Some researchers have analysed the possibility that remittances are motivated by self-interest and respond to investment or portfolio variables (Faini, 1994, El-Sakka and McNabb, 1999). Others, such as Amuedo-Dorantes and Pozo (2006a) have studied whether remittances are sent as part of a co-insurance contract with their families or as self-insurance by accumulating precautionary savings back home in case of income uncertainty in the host country. They provide empirical evidence of the insurance explanation by linking migrants' remittances to the level of uncertainty in the host country, even though they acknowledge data limitations to properly measure income risk (variance of projected stream of income). They use proxy variables as an alternative for income uncertainty based on certain characteristics of migrants such as legal status, receipts of fringe benefits, work experience in US, etc.

There are several studies (Amuedo-Dorantes et al., 2002, Lusardi, 1998, Carrol and Sanwick, 1998, Guiso et al., 1992) that have analysed income uncertainty and how it relates to precautionary savings, all of them mainly differing in the way they derive a measure of uncertainty. Lusardi (1998) uses subjective probabilities of job loss as a measure of income variance while Carrol and Sanwick (1998) opt for the variance of the logarithmic of income. Amuedo-Dorantes et al. (2002) point out that this strategy is not suitable for a panel data analysis since it is a constant measure for the entire period under examination. Instead, they suggest a measure of uncertainty that captures the average unexplained income relative to predicted income over time, constructed with the average sum of square residuals of annual regressions of the logarithmic of income. Amuedo-Dorantes et al. (2002) shows that precautionary savings increase as income uncertainty increases and natives carry out more precautionary savings than migrants. They attribute the later result to the possibility of migrants accumulating part of their saving in their home countries through remittances.

Illegal migrants face a high degree of income uncertainty which seems intrinsic to their clandestine status in the host country. As a result, their perception of an increase probability 
of deportation due to a policy change like IIRIRA may trigger precautionary savings sent to their home countries as remittances for self-insurance purposes. Amuedo-Dorantes et al. (2010) have shown that an amnesty program (IRCA) for illegal migrants implemented in US in 1986 affected migrants behaviour, leading to a reduction in their propensity to remit money home. They explain this change as resulting from a reduction in their perception of uncertainty regarding their migration experience when they obtain a legal status in the host country.

Dustmann (1997) has framed in a theoretical model whether precautionary savings from migrants' workers differ from those of comparable locals taking into consideration the temporary nature of migration and the existence of income uncertainty in both host and home country. He point out that if migrants workers perceive the host country labour market as riskier than do local workers the variance of their income accumulated abroad should be higher especially for particular cases such as illegal migration where migrants normally are relegated to jobs with high degree of uncertainty and with no rights to claim any benefit support in the host country. Consequently, he concludes that if migrants subjectively perceive higher income uncertainty (higher income variance) they are likely to accumulate higher precautionary savings than the local workers.

Our study presents an empirical application of Dustmann's approach by testing whether the IIRIRA reform prompted an increase in remittances from Mexican illegal migrants who may have perceived a higher level of uncertainty resulting from their irregular situation in the US. The data shows that these migrants face higher income variance after the reform compared to their legal counterparts. This gives some support to what we point out as an increase in their perceived uncertainty in the host country.

\section{Theoretical Model}


We use a simple approach that focuses on the way migrants choose consumption in the home country now versus consumption in their own countries when they return, following Dustmann and Kirchkamp (2002). The migrant head of household derives utility from consumption whether in the host country $\left(C_{1}\right)$ or at home when returns $\left(C_{2}\right)$ and is constrained by the wages they received in the host $\left(\mathrm{W}_{\mathrm{f}}\right)$ and home countries $\left(\mathrm{W}_{\mathrm{h}}\right)$, respectively. Immigrants allocate a probability $p \in[0,1]$ to the prospect of being caught and deported if entering the country illegally (if $\mathrm{p}=0$ the immigrant is legally entitled to resettle). This probability is intended to formalise the idea that an illegal migrant facing a higher chance of being caught than someone moving legally is likely to engage in less risky and visible behaviours about his/her consumption pattern. Migrants have a perfect knowledge of their wages in their home $\left(\mathrm{W}_{\mathrm{h}}\right)$ and host country $\left(\mathrm{W}_{\mathrm{f}}\right)$ and wages are, by definition, higher abroad $\left(\mathrm{W}_{\mathrm{f}}>\mathrm{W}_{\mathrm{h}}\right)$. The optimization problem facing the migrant with utility:

$$
U=(1-p) \times \ln C_{1}+(p) \times \ln C_{2}
$$

and facing the budget constrain:

$$
(1-p)\left[W_{f}-C_{1}\left(p_{s}\right)\right]+p\left[W_{h}-C_{2}\right]
$$

is formally represented in the Lagrangian:

$$
L=(1-p) \times \ln C_{1}+p \times \ln \left(C_{2}\right)+\lambda\left[(1-p)\left(W_{f}-C_{1}\right)+p\left(W_{h}-C_{2}\right)\right]
$$

The migrant maximizes utility by choosing the optimal levels of consumption in the host and home country $\left(\mathrm{C}_{1}\right.$ and $\left.\mathrm{C}_{2}\right)$ which in turn determine the optimal level of remittances. The first order conditions yield an expression for the optimal level of $C_{1}$ and $C_{2}$ respectively:

$$
\frac{\partial U}{\partial C_{1}}=\left(\frac{(1-p)}{C_{1}}\right)-\lambda(1-p)=0 \Rightarrow C_{1}^{*}=\frac{1}{\lambda}
$$


$\frac{\partial U}{\partial C_{2}}=\left(\frac{p}{C_{2}}\right)-\lambda[p]=0 \Rightarrow C_{2}^{*}=\frac{1}{\lambda}$

$\frac{\partial U}{\partial \lambda}=(1-p)\left[W_{f}-C_{1}\right]+(p)\left[W_{h}-C_{2}\right]=0 \Rightarrow(1-p) W_{f}+(p) W_{h}=\frac{1}{\lambda}=C_{1}=C_{2}$

Since we can define remittances $\left(\mathrm{R}^{*}\right)$ as $\left(W_{f}-C_{1}\right)$, the first order conditions for the maximization problem provide as well the optimal level of remittances:

$R^{*}=\left(W_{f}-C_{1}\right)^{*}=p \times\left(W_{f}-W_{h}\right)$

The effect of the policy change on illegal migrants' remittances is represented by a higher probability (p) of a forced return (deportation) to the home country. This increases migrants’ perception of uncertainty and in turn leads to higher (optimal) remittances.

\section{Data}

We use data from the Mexican Migration Project (MMP128) which is a collaborative research project based at the Princeton University and the University of Guadalajara (mmp.opr.princeton.edu). The MMP128 survey contains information from 21,475 household heads out of which 7,237 have immigrated to the USA at some point. The project started in 1982 and contains data for every year since 1987. Each year, the MMP interviews a random sample of 200 households in two to five Mexican communities. Since communities are not selected randomly, the survey is strictly representative only for the populations of the 128 communities surveyed, with the major advantage that those communities reflect a broad range of sizes and socioeconomic conditions. Because the survey is geographically focused in Western Mexican states it seems to be biased, but a comparison performed by Massey and Zenteno (2000) to a national representative survey has shown a great degree of accordance.

Our analysis starts with the selected sample of 7,237 household heads that had migrated to the USA since this subset contains the relevant information for the estimations. We then 
restrict the sample only to household heads whose last migration was reported after 1989 . To choose this particular date as the first year of the sample may seem like a reasonable strategy since an amnesty for illegal migrants was introduced in November 1986 (IRCA) and following a slow implementation period, lasted for approximately two years and significantly affected the behaviour of Mexican migrants regarding remittances (Amuedo-Dorantes et al, 2010). So the pre-IIRIRA period consists of information from 1990-1996 and the postIIRIRA period consists of information from 1997-2008. These restrictions reduce the sample to 2,756 observations.

The study requires valid calculable remittances and monthly wages information pre-IIRIRA and post-IIRIRA law. We therefore we narrow the sample to account for the missing values, outliers and non-responses to these questions. This restricts the sample to 1,994 observations. We also limit the data to consider non-responses to relevant questions such as employment status of migrant' spouse, property tenancy, whether migrant obtain financial help and if migrant contacted community members upon arrival to USA. This further reduces the sample to 1,914 observations. Finally, we eliminate observations that represent migrants who were present in US in 1997 (variable derived by combining year of last trip and duration of last trip) resulting in a final sample with 1,806 observations.

The analysis of the impact of the IIRIRA on migrants' behaviour is primarily performed focusing on the remittances' flows from legal and illegal migrants who might face different degrees of uncertainty before and after its implementation. All undocumented migrants who were present in the US after April $1^{\text {st }}$, 1997 were potentially subject to the sanctions imposed by the law.

A number of socio-economic and demographic characteristics of the household head are included as explanatory variables for migrants' remittances. These are the age, monthly wage during the last trip to the US, the number of household members, and a set of dummy 
variables differentiating migrants by individual and family characteristics such as the employment situation of the spouse, father or mother residing in US, property ownership, sector of employment, level of education, and if the last trip was after 1997.

The descriptive statistics are shown in the Appendix (Table 1). They reveal that the average monthly wage for illegal migrants is $13.2 \%$ lower than for legal migrants, but they remit a bigger portion of their income. Illegal immigrants remit $26.5 \%$ of their earning while legal migrants remit $22 \%$. Over $83.5 \%$ of the illegal migrants remit on a regular basis vis-à-vis the 74.6\% for legal migrants. Undocumented head of households are also younger (36.6 vs. 40.5 years old), slightly less educated, and less likely to be married than legal migrants. In terms of house ownership, both groups have similar likelihood to own their houses or apartments with $65.3 \%$ of owners who are legal migrants and $60 \%$ are undocumented.

A few variables in the model capture social capital relevant to migration which includes any social relationship or regular interpersonal contact that facilitates the process of adaptation and mutual assistance (Massey et al. 1997). The dummy variable indicating whether members of the same community of origin have been contacted upon arrival to the US shows that $63 \%$ of legal and $66 \%$ of illegal migrants meet with people that come from the same Mexican place of origin. These contacts may facilitate faster integration of migrants into the US labour market but also might offer a faster and easier possibility to transfer money home by informal channels.

Although the main advantage of using MMP128 is that it covers both legal and illegal migrants and provides information on migrants' remittances, one of its main drawbacks is that does not constitute a true panel as it samples different individuals every year. This could invalidate the results of the quasi-experiment because migrants interviewed before the treatment (IIRIRA) are not the same to those who were interviewed after it. 


\subsection{Identification Strategy:}

The two main strategies about identification need to be discussed. The first relates to the identification of who was present in the US at the time of the IIRIRA. We have:

- $\quad$ migrants who were present in USA after $1^{\text {st }}$ April 1997: 898 observations from which 600 were undocumented and 298 were legal migrants.

- $\quad$ migrants who were not present in USA after $1^{\text {st }}$ April 1997: 908 observations from which 480 were undocumented and 428 were legal migrants.

The MMP128 survey contains a set of questions that provides information about the last migration trip. Since we do not have the exact date when a migrant was present in US, we have constructed a new variable combining the information from two of the survey questions: one asking when was the year of the last trip to US and the other with the duration of the last trip in months. This variable reflects the year were a migrant was present in US and helps to identify the group subject to the analysis (migrants present is US after IIRIRA) ${ }^{1}$. In order to capture the relevant group of migrants, our strategy is to exclude from the sample the observations of this new variable that fall in 1997. This leaves us with two groups of migrants clearly identified: migrants who were in US after 1997 and had migrated before or after that year; and those who were not in US by 1997 and the duration of their trip was not long enough to be in US by the time IIRIRA was implemented (April 1997).

The second is that, not having a 'true' panel, we face the possibility that unobservable individual characteristics underpin the change in remitting behaviour rather than the actual IIRIRA. To deal with this issue we test that the control group (legal migrants) before and

\footnotetext{
${ }^{1}$ The new variable was constructed as follows: USYRL1=USYRL+(USDURL/12) where USYRL is the year of last migration trip and USDURL is the duration of the last trip in months. The results were rounded to the nearest year in order to get a whole year. In addition, a dummy variable was created which equals 1 if USYRL >1997 and zero otherwise to identify the relevant groups for the analysis.
} 
after 1997 is homogeneous and has similar demographic, human capital, employment and trip characteristics. The Kruskal-Wallis test supports that differences pre- and post-IIRIRA in the control group are not statistically significant and hence the null hypothesis of equality of population medians among groups cannot be rejected. This gives us some degree of confidence in interpreting the estimates as resulting from the policy change rather than individual heterogeneity.

\section{Empirical Methodology}

To assess the effect of the policy we use a difference-in-difference (DiD) methodology, characterized by the following equation:

$$
R_{i}=X_{i} \beta+\beta_{1} I_{i}+\beta_{2} Y+\beta_{3} I_{i} * Y+X_{i} I_{i} \beta_{4}+\varepsilon_{i}
$$

where $\mathrm{R}$ represents the inverse hyperbolic sine of migrant' remittances, $\mathrm{X}$ is a vector of covariates that includes individual characteristics, trip characteristics, community, and employment characteristics, $\mathrm{I}$ is a dummy variable indicating illegal migration, and $\mathrm{Y}$ is a time period dummy that indicates presence in US after 1997. The estimate of the coefficient $\beta_{3}$ will show the impact of the policy reform on the treatment group: migrants present in USA illegally after $1^{\text {st }}$ of April 1997.

We deem it preferable to use this approach to those which compare the difference in outcomes between legal and illegal migrants measured after the IIRIRA has been introduced, as the latter approach do not reveal the effect of the policy change. Undocumented migrants tend to differ from their legal counterparts even in the absence of the intervention. The MMP database provides information on remittances (outcome variable) for legal and illegal migrants observed before the IIRIRA. The main limitation of performing a difference-indifferences estimation is that we cannot entirely satisfy the assumptions that treated and non- 
treated groups are subjected to the same counterfactual trend. Since the MMP data consists of repeated cross-sections, the characteristics of the control and treatment group could be different and follow different trends. We test this possibility for the control group by checking that the characteristics before and after the treatment are not statistically significantly different. The tests support viewing the two groups as coming from the same population.

We use Ordinary Least Squares (OLS) to perform the estimations. The difference-indifference estimates show strong evidence that illegal migrants remit more after the IIRIRA reform than their legal counterparts. This suggests that migrants effectively act self-interested and transfer more money to their home countries in order to be covered in the case of an eventual deportation (insurance purpose).

One important issue to contemplate with the OLS estimation is that the parameters could be biased because a significant percentage of the migrants deny remitting; consequently the dependent variable in the analysis (remittances) is censored at zero. The bias arises from the fact that OLS only consider the positive observations and omit the others. It is no guarantee that expected value of the error term $\mathrm{E}\left(\varepsilon_{i}\right)$, will be necessarily equal to zero (Gujarati, 1985). Depending on the proportion of constrained (censored) observations, the size of the bias may constitute a problem that need to be addressed in order to obtain better estimators (unbiased) for the model.

Following the literature, we employ a Tobit model to correct for the biases estimators, which has been used widely for cases of censored or "corner solution responses”. According to this model, the variable of interest (remittances) can be presented as:

$$
\begin{aligned}
& R_{i}^{*}=\beta X_{i}+\varepsilon_{i} \quad \text { and } \quad \varepsilon_{i} \mid X \sim \operatorname{Normal}\left(0, \sigma^{2}\right) \\
& R_{i}=R_{i}^{*} \quad \text { if } \quad R_{i}>0
\end{aligned}
$$




$$
R_{i}=0 \quad \text { if } \quad R_{i}^{*} \leq 0
$$

Where $R_{i}^{*}$ is a latent variable satisfying the classical linear model assumptions of normal, homoskedastic distribution with a linear conditional mean. The estimation uses maximum likelihood methodology which combines the probit and regression components of the loglikelihood function, expressed as:

$\log L\left(\beta, \sigma^{2}\right)=\sum_{i \in I_{0}} \log \left[1-\phi\left(\frac{\beta X_{i}}{\sigma}\right)\right]+\sum_{i \in I_{1}} \log \left[\frac{1}{\sqrt{2 \pi \sigma^{2}}} \exp \left[-\frac{1}{2} \frac{\left(R_{i}-\beta X_{i}\right)^{2}}{\sigma^{2}}\right]\right]$

Maximization of this function with respect to $\beta$ and $\sigma^{2}$ yields the maximum likelihood estimates. The index sets $\mathrm{I}_{0}$ and $\mathrm{I}_{1}$ are defined as the sets of those indexes corresponding to the zero and positive observations respectively. $R_{i}$ represents the inverse hyperbolic sine of remittances, and $X_{i}$ is a vector of covariates referring to individual characteristics including the dummy variables created to identify the group affected by the IIRIRA program.

One of the limitations of the Tobit I model is that the expected value conditional on remittances being positive ( $R_{i}>0$ ) is closely linked to the probability (participation decision) that an individual remit a positive amount (Wooldridge, 2006). To consider this possibility, several alternative models have been developed depending of the treatment of zeros. Tobit II model addresses the case associated with the non-participation decision using a maximum likelihood estimation procedure assuming that the zero observations surge from the migrants’ self-selection, as opposed to the Tobit I model, which ignores the 'source' of the zeros. The model assumes that the error terms are correlated with a bivariate normal distribution and the zeros are only the result of migrants’ deliberate decision of non-participation.

The same Tobit II model can also be estimated by the Heckman two-step procedure. This does not assumes bivariate distribution for the error terms and estimates the first step (participation) by Probit and the second step by OLS including the inverse of the Mills' ratio 
in this regression as an additional explanatory variable in order to correct for the selection bias.

Another model that overcomes such limitation is the double-hurdle or two-part model which is a generalization of the Tobit I and allows for the possibility that the zeros are generated not only by migrants' choices but also by random circumstances. The first hurdle of the model is a binary outcome equation modelling the $\operatorname{Pr}\left(R_{i}>0\right)$, defining a binary indicator such as $\mathrm{r}=1$ if $R_{i}>0$ and $\mathrm{r}=0$ if $R_{i}=0$. The second hurdle uses a linear regression (OLS) to modelE $\left(\ln R_{i} \mid R_{i}>0\right)$. The two parts are assumed to be independent and estimated separately. Since in this paper the participation decision and the level of remittances are constructed from the same question, we only observe zeros derive from non-participation in which case this model would be equivalent to the Tobit II estimated by the Heckman two steps procedure previously discussed.

It is important to notice that some of these models depend on the assumption of normality and homoskedasticity of the errors. Regarding normality, the literature proposes to transform the dependent variable whenever it is censored and over dispersed, which is the case for remittances in our data. One of the most common practices is to use the logarithmic transformation of the dependent variable, but it would imply discarding the observations with zero or non-positive values. Since a significant number of observations are zero for our dependent variable, we have chosen to use the inverse hyperbolic sine (IHS) of remittances, which is defined as: $R_{i}^{T}=\ln \left(R+\sqrt{\gamma^{2} R^{2}+1}\right) / \gamma$ where $\gamma$ is a scaling parameter that we have assumed equal to one. Because the IHS function is symmetric around zero in $\gamma$ we can consider only values of $\gamma \geq 0$. This transformation is linear when $\gamma$ approaches zero and is simply a vertical displacement of the logarithmic for large values of the dependent variable (Burbidge et al., 1988). Figure 5 on the appendix shows the similarity of the logarithmic and 
IHS functions using the dependent variable of interest which is the value of monthly remittances.

\section{Results}

Table 2 and Table 3 include all the estimates of the difference-in-differences technique. Table 2 reports the results from the OLS and the Tobit I model while Table 3 shows the results for the Tobit II model and the independent double-hurdle model. The outcomes indicate that selection bias is not problematic since the results of the likelihood ratio test (LR test) show that the correlation between the errors in both parts of the model (probability and level of remittances) is not significantly different from zero. Furthermore, when the Tobit II model is estimated by the two-step procedure, the coefficient for the Mills ratio which would evidence the existence of selection is also no-statistically significant.

The initial estimations from the OLS model presented in Table 2 confirm that remittances from illegal migrants after the implementation of the IIRIRA are higher (56.7\%) than for their legal counterparts. This result is consistent with the possibility of an increase in the level of uncertainty perceived by undocumented migrants because of the tougher controls and penalties associated to their irregular legal status. Given that OLS estimations only consider the positive observations, this result is bias and needs to be corrected. The Tobit I model estimations presented in the same table address this issue.

The coefficients in the Tobit I model measure the effect of changes in each explanatory variable on the expected value of the latent variable $\left(R_{i}^{*}\right)$. However, the variable of interest is the observed level of remittances from illegal migrants denoted by $R_{i}$. Therefore the coefficients results and standard errors from this model are presented together with their marginal effects which reflect the elasticities or semi-elasticities of the dependent variable evaluated at the respective means of the independent variables. Table 2 show these effects, 
first on the probability of remitting denoted by $\left.\partial P\left(R_{i}>0 \mid X_{i}\right) / \partial X_{i}\right)$ and then on the conditional expectation which is symbolized by $\partial\left(E\left(R_{i} \mid R_{i}>0, X_{i}\right)\right) / \partial X_{i}$.

In general, the results from the Tobit I model in Table 2 indicate that illegal migrants who were present in USA after the policy change are $2.26 \%$ more likely to remit a positive amount than their legal counterparts. Moreover, the results show that those who decide to remit are transferring $52 \%$ more than they did in the years preceding the reform, which is also consistent with the possibility of migrants perceiving higher degree of uncertainty in the host country.

There are other factors that affect migrants' remittances and present statistically significant results with most of the coefficient signs in line with the findings from the literature and remittances' theory. Migrants' level of education does not play an important role in determining the probability or the magnitude of transfers to the home country ${ }^{2}$. In contrast, marital status is an important explanatory variable: married migrant have $3.8 \%$ higher probability of sending money home and the amount is $67.5 \%$ greater than that of singles. Spouse employment status is also highly significant with marginal effects showing that migrants are less likely (2.2\%) to remit if their partners are employed and the amount is 44.1\% less than is the case when the spouse is unemployed or simply not participating in the labour market.

As expected, migrants remittance decisions are also highly related both to their wages in the US and to assets ownership in Mexico, particularly if they own the house where the family reside. The marginal effects show that the probability of remitting increases by $1.63 \%$ with an increase in the migrant wage and the amount remitted is $35.2 \%$ higher. If the remitters own a

\footnotetext{
${ }^{2}$ Results including all the education covariates and different specifications for the model are available from the authors upon request.
} 
house in Mexico they are $2.7 \%$ more likely to remit and the level of remittances will be 56\% higher than would be otherwise.

The results from variables associated with the existence of family members living in the US or people from the same community that provide support upon arrival suggest that if such circumstances occur, the likelihood to remit is $2.1 \%$ higher. The amount transferred is also 42.7\% larger in such cases. Having members of the same community of origin living in the host country may make it relatively easier to send money home via informal channels, especially for undocumented migrants with limited access to the formal financial system.

Although the coefficient for legal status is not statistically significant, the sign is consistent with the theory, confirming that undocumented migrants tend to remit more than their legal counterparts. When legal status is interacted with the variable representing presence in the US after 1997 to account for the effect of the IIRIRA, the resulting coefficient is significant, corroborating the main argument of this paper that illegal migrants remit more money (52\%) to their home countries as a self-insurance mechanism against a perceived higher uncertainty generated by a policy reform that tighten the controls regarding their legal status.

\section{Conclusions:}

Public policy concerning illegal migrants is under discussion in the US and elsewhere and there is a general consensus within the government and the general public that something needs to be done to curb it. This study has examined how Mexican undocumented migrants’ remitting behaviour changes as a result of the US Illegal Immigrant Reform and Immigrant Responsibility Act of 1996 (IIRIRA). The results support that the IIRIRA affected migrants' migrants' perception of uncertainty about their future in the host country increased and therefore responded by sending more money to Mexico as a way to self-insure. 
The robustness of the estimations is checked by different tests designed to analyse the characteristics of the control group (legal migrants) before and after the policy reform, corroborating that legal migrants have similar characteristics when evaluated over time and both groups have been generated randomly by the same population.

The results highlight that host country policies targeting illegal migrants are more likely to trigger an outflow of remittances. Those resources however not only constitute a major balance of payment item for emigration countries, but can also contribute to the pool of domestic savings and financial resources available for investment in the country of destination. A deeper understanding of migrants' remitting behaviour may lead to migration policies that result not only in facilitating the economic and social integration of immigrants, but also contribute to the efficient use of host country's public resources.

\section{References:}

Agarwal, R., A., Horowitz. (2002) Are International Remittances Altruism or Insurance? Evidence from Guyana Using Multiple-Migrant Households. World Development, 30(11), 2033-2044.

Amuedo-Dorantes, C., Bansak Cynthia. (2006). Money Transfers among Banked and Unbanked Mexican Immigrants. Southern Economic Journal, 73(2), 374 - 401.

Amuedo-Dorantes, C., Pozo Susan. (2006a). Remittances as Insurance: Evidence from Mexican Migrants. Journal of Population Economics, 19(2), 227-254.

Amuedo-Dorantes, C., Mazzolari F. (2010). Remittances to Latin America from migrants in the United States: Assessing the impact of amnesty programs. Journal of Development Economics, 91, 323-335.

Amuedo-Dorantes, C., Pozo Susan. (2002). Precautionary Savings by Young Immigrants and Young Natives. Southern Economic Journal, 69(1), 48-71.

Bauer, Thomas K., Sinning, M. (2005). Blinder-Oaxaca Decomposition for Tobit Models. IZA Discussion Paper No 1795. 
Burbidge, John B., Magee Lonnie, Robb Leslie (1988). Alternative transformations to handle extreme values of the dependent variable”. Journal of the American Statistical Association, 83 (401), 123-127.

Dustmann, Christian. Return Migration, Uncertainty and Precautionary Savings. Journal of Development Economics, 52, 295-316.

Dustmann, C., Kirchkamp, O. (2002). The Optimal Migration Duration and Activity Choice after Re-migration. Journal of Development Economics, 67, 351-372.

El-Sakka, M. I. T., Mcnabb Robert. (1999). The Macroeconomic Determinants of Emigrant Remittances. World Development, 27, 1493 - 1502.

European Commission. (2009). Undocumented Migration: counting the uncountable. Data and Trends across Europe. The CLANDESTINO Research Project. European Commission, project no. CIS8-04410.

Fafchanps, M., Lund Susan. (2003). Risk-sharing Networks in Rural Philippines Journal of Development Economics, 71(3), 261-287.

Faini, R. (1994). Workers' Remittances and the Real Exchange Rate: A Quantitative Framework. Journal of Population Economics, 7, 235 - 245.

Greene, W., H. (2000). Econometric Analysis, New York: Macmillan.

Jann, Ben. (2008). A Stata implementation of the Blinder-Oaxaca decomposition. ETH Zurich Sociology. Working Paper No 5.

Lucas, R., Stark Oded (1985). Motivations to Remit: Evidence from Botswana. Journal of Political Economy, 93(5), 901-918.

Massey, D., S., Espinosa, K., E. (1997). What’s driving México-US migration? A theoretical, empirical and policy analysis. American Journal of Sociology, 102, 939-999.

Massey, D., Zenteno R., (2000). A Validation of the Ethnosurvey: The case of Mexico-U.S. Migration. International Migration Review, 34(3), 766 - 793.

OECD (2010). Development Cooperation Report 2010. OECD.

Osili, U. O. (2007). Remittances and Savings from International Migration: Theory and Evidence using a Matched Sample. Journal of Development Economics, 83, 446-465.

Passel, J., Cohn, V. (2009). A portrait of unauthorized immigrants in the United States. April 
Report from the Pew Hispanic Center. Washington D.C.

Piracha, M., Zhu, Y. (2007). Precautionary Savings by Natives and Immigrants in Germany. IZA Discussion Paper, No 2942.

Ratha Dilip, Mohapatra S., Silwal A. (2011). Migration and Remittance Factbook 2011, $2^{\text {nd }}$ Edn. The World Bank.

Rivera-Batiz Francisco, L. (1999). Undocumented Workers in The Labour Market: An Analysis of the Earning of Legal and Illegal Mexican Immigrants in the United States. Journal of Population Economics, 12(1), 91-116.

Sinning, M. (2007). Determinants of Savings and Remittances: Empirical Evidence from Immigrants to Germany. IZA Discussion Paper, No 2966.

United States. Department of Homeland Security (2010). Yearbook of Immigration Statistics: 2009. US Department of Homeland Security, Office of Immigration Statistics. Washington, D.C.

Visalaw.com (2007). IIRIRA 96 - A Summary of the new Immigration Bill. Retrieved November 29, 2010, from http://www.visalaw.com/96nov/3nov96.html\#section\%205.

Wooldridge, J. M. (2006). Introductory econometrics: a modern approach, $4^{\text {th }}$ edn. Thomson South-Western, Mason, $\mathrm{OH}$.

World Bank (2008). World Tables. Washington. The World Bank. 


\section{Appendix:}

Figure 1: Mexican Remittances - \% of Official Development Assistance (ODA)

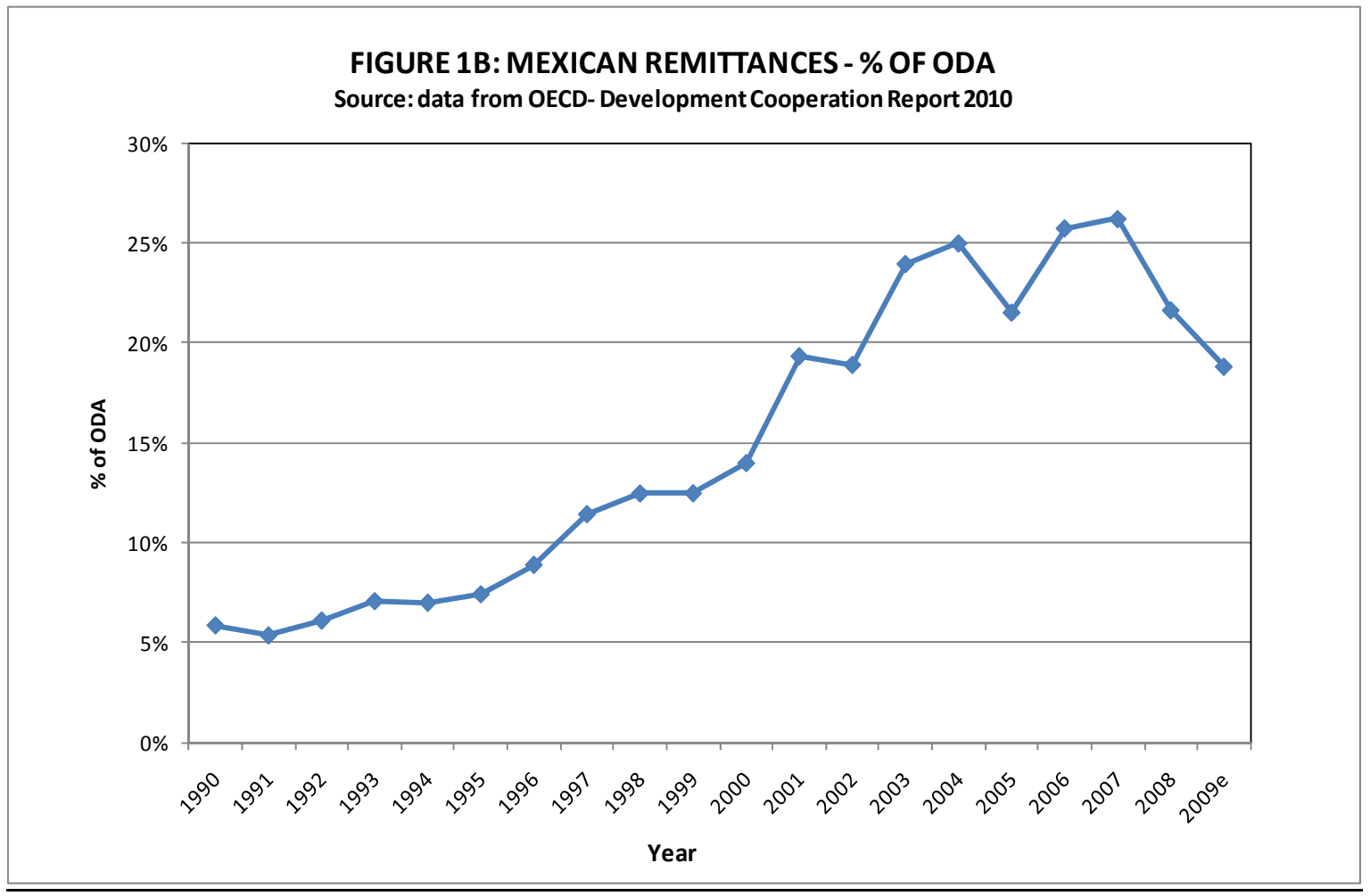

Figure 2: Number of migrants removed/returned from USA (\% change)

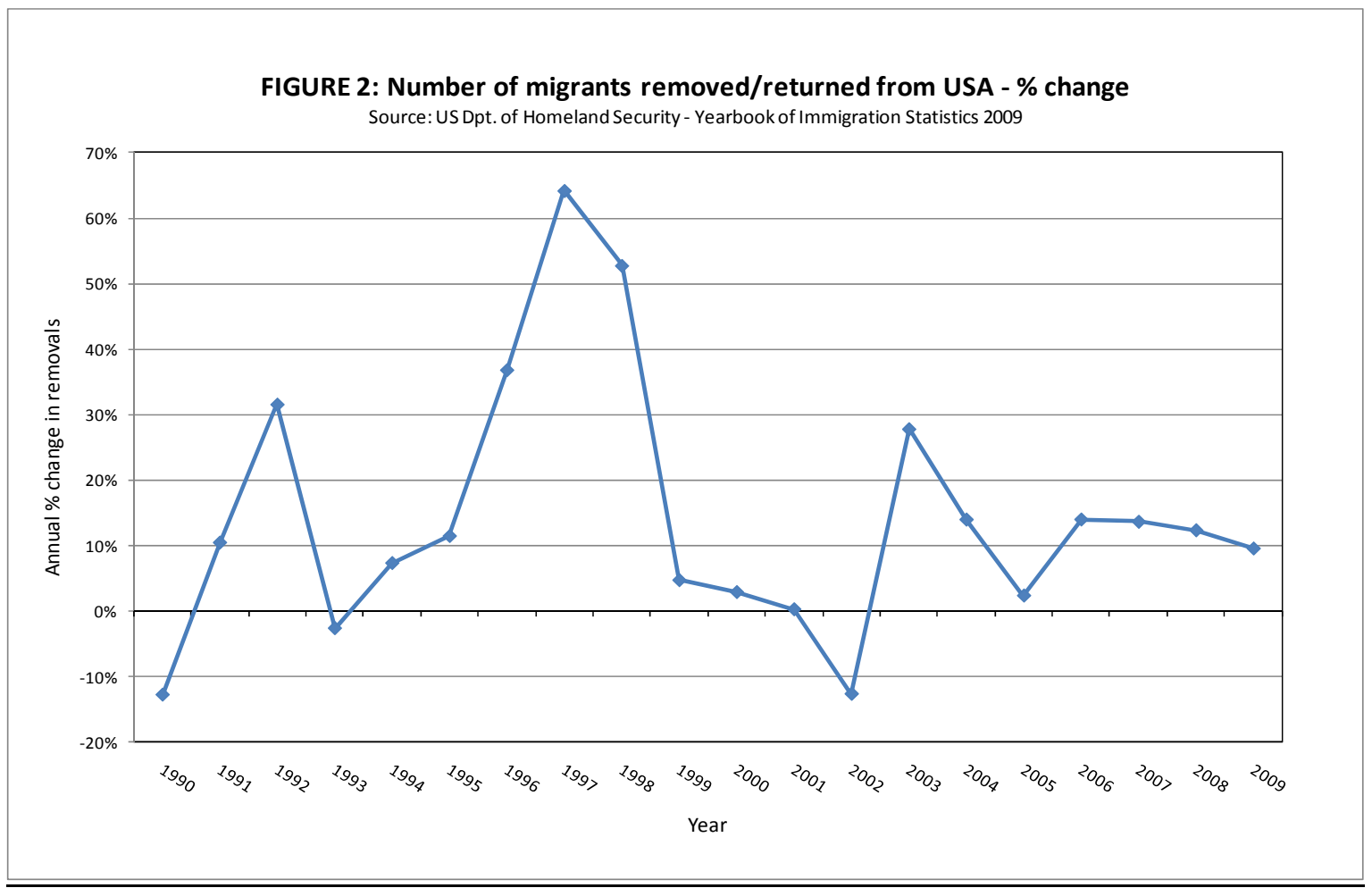


Figure 3: Remittances from illegal migrants during their last trip to USA (MMP database)

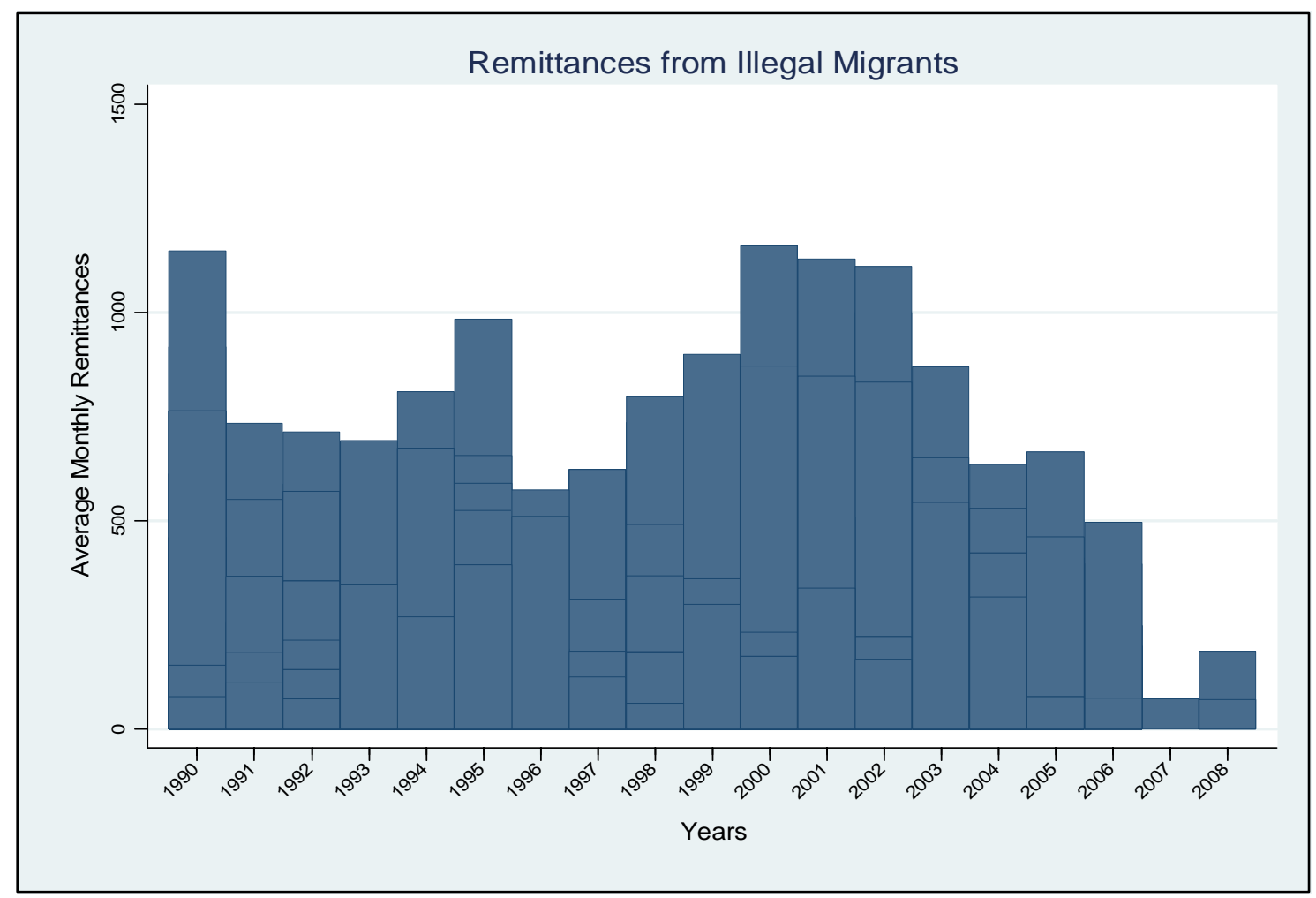

Figure 4: Remittances from legal migrants during their last trip to USA (MMP database)

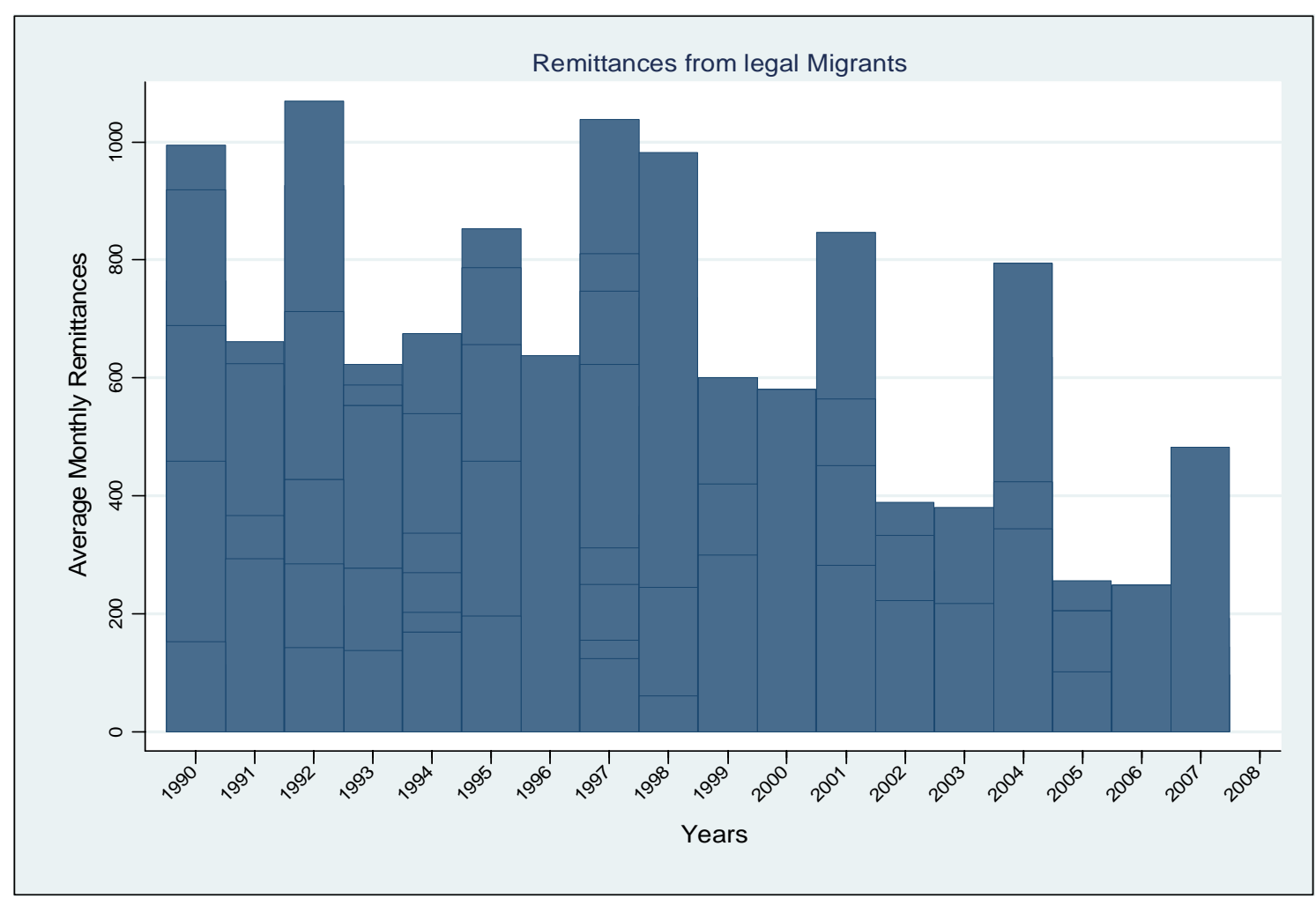


Figure 5: Monthly Remittances - Logarithmic and Inverse Hyperbolic Sine Functions

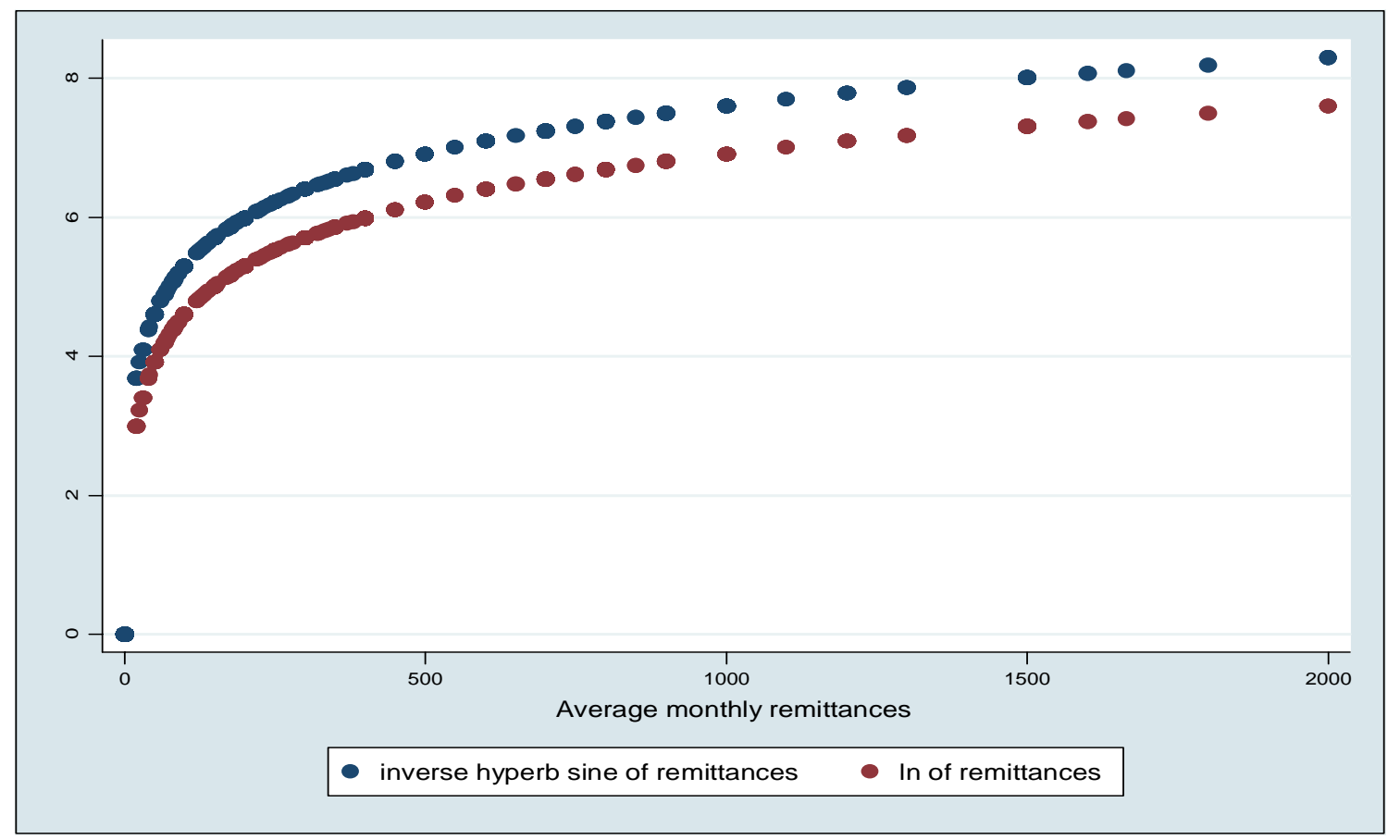

Table 1: Descriptive Statistics

\begin{tabular}{|c|c|c|c|c|c|c|c|}
\hline \multirow{2}{*}{ Variable } & \multirow{2}{*}{ Definition } & \multicolumn{2}{|c|}{ ALL MIGRANTS } & \multicolumn{2}{|c|}{ LEGAL MIGRANTS } & \multicolumn{2}{|c|}{ ILLEGAL MIGRANTS } \\
\hline & & Mean & S.D. & Mean & S.D. & Mean & S.D. \\
\hline rremit & Remittances (US\$ of 1984) & 197.232 & 193.498 & 190.963 & 197.964 & 201.447 & 190.414 \\
\hline rwage & Real wage (US\$ of 1984) & 809.383 & 463.178 & 878.756 & 525.220 & 762.748 & 410.018 \\
\hline age & Age of the household head & 38.177 & 11.043 & 40.609 & 11.780 & 36.542 & 10.203 \\
\hline members & Total number of members in household & 4.639 & 2.039 & 4.649 & 2.041 & 4.632 & 2.039 \\
\hline dmarried & Dummy marital status of household head & 0.858 & 0.349 & 0.902 & 0.297 & 0.828 & 0.378 \\
\hline dspempl & Dummy spouse employment status & 0.213 & 0.410 & 0.233 & 0.423 & 0.200 & 0.400 \\
\hline edyrs & Household head formal education (in years) & 12.019 & 235.163 & 6.409 & 3.942 & 15.791 & 304.081 \\
\hline dedcat 1 & Dummy education ( 1 =some schooling) & 0.188 & 0.391 & 0.215 & 0.411 & 0.169 & 0.375 \\
\hline dedcat2 & Dummy education (1=primary uncompleted) & 0.095 & 0.293 & 0.106 & 0.308 & 0.087 & 0.282 \\
\hline dedcat3 & Dummy education (1=primary or higher) & 0.665 & 0.472 & 0.627 & 0.484 & 0.691 & 0.462 \\
\hline dpaistrip & Dummy community members contacted ( $1=y e s$ ) & 0.652 & 0.477 & 0.631 & 0.483 & 0.666 & 0.472 \\
\hline duscurtrp & Dummy currently in the last trip ( $1=y e s)$ & 0.277 & 0.448 & 0.351 & 0.478 & 0.227 & 0.419 \\
\hline usdurl & Total duration of the last trip (in months) & 20.613 & 25.873 & 17.438 & 25.932 & 22.747 & 25.624 \\
\hline dproten & Dummy property tenancy ( $1=$ owner $)$ & 0.625 & 0.484 & 0.653 & 0.476 & 0.606 & 0.489 \\
\hline dhelp & Dummy received financial help upon arrival (dhelp) & 0.687 & 0.464 & 0.609 & 0.488 & 0.739 & 0.439 \\
\hline
\end{tabular}




\begin{tabular}{|c|c|c|c|c|c|c|c|}
\hline \multirow{2}{*}{ VARIABLES } & \multirow{2}{*}{$\begin{array}{l}\text { OLS } \\
\text { Coeff. }\end{array}$} & \multicolumn{6}{|c|}{ TOBIT I } \\
\hline & & Coeff. & $\begin{array}{l}\text { Marg. Eff. } \\
\text { Pr(remit) }\end{array}$ & $\begin{array}{l}\text { Marg. Eff. } \\
\text { Remitt. }\end{array}$ & Coeff. & $\begin{array}{l}\text { Marg. Eff. } \\
\text { Pr(remit) }\end{array}$ & $\begin{array}{l}\text { Marg. Eff. } \\
\text { Remitt. }\end{array}$ \\
\hline \multirow[t]{2}{*}{ illegal migrant } & 0.5016 & 0.7285 & 0.02812 & 0.5769 & 0.3134 & 0.01181 & 0.2493 \\
\hline & $(0.4072)$ & $(0.5286)$ & $(0.02152)$ & $(0.4148)$ & (0.2288) & $(0.008896)$ & $(0.1811)$ \\
\hline \multirow[t]{2}{*}{ in US after IIRIRA } & $0.6625^{\star \star \star}$ & $0.8005^{\star \star \star}$ & $0.02974^{\star \star *}$ & $0.6388^{\star \star \star}$ & $0.8048^{\star \star \star}$ & $0.02992^{\star \star \star}$ & $0.6421^{\star \star *}$ \\
\hline & $(0.2074)$ & $(0.2712)$ & $(0.01070)$ & $(0.2153)$ & $(0.2584)$ & $(0.01028)$ & $(0.2049)$ \\
\hline \multirow[t]{2}{*}{ illegal in US after IIRIRA } & $0.5675^{\star \star}$ & $0.6451^{*}$ & $0.02261^{\star \star}$ & $0.5205^{\star}$ & $0.6496 * \star$ & $0.02277^{\star \star}$ & $0.5241^{\star *}$ \\
\hline & $(0.2645)$ & (0.3292) & $(0.01124)$ & $(0.2678)$ & (0.3096) & (0.01059) & $(0.2520)$ \\
\hline \multirow[t]{2}{*}{ Household: Total number of members } & $0.08282^{*}$ & $0.1074^{\star}$ & $0.003977^{*}$ & $0.08574^{*}$ & $0.09125^{\star \star \star}$ & $0.003381^{\star *}$ & $0.07282^{\star \star \star}$ \\
\hline & $(0.04674)$ & (0.06008) & $(0.002273)$ & $(0.04787)$ & (0.03375) & $(0.001324)$ & (0.02673) \\
\hline \multirow[t]{2}{*}{ spouse employed } & $-0.4478^{\star \star \star}$ & $-0.5629^{\star \star \star}$ & $-0.02273^{\star \star *}$ & $-0.4415^{\star \star \star}$ & $-0.5524^{\star \star \star}$ & $-0.02228^{\star \star \star}$ & $-0.4333^{\star \star \star}$ \\
\hline & $(0.1427)$ & $(0.1890)$ & (0.008630) & (0.1450) & $(0.1878)$ & (0.008543) & $(0.1443)$ \\
\hline \multirow[t]{2}{*}{ married } & $0.6773^{\star \star \star}$ & $0.8762^{\star \star \star}$ & $0.03831^{\star \star \star}$ & $0.6753^{\star \star \star}$ & $0.9544^{\star * *}$ & $0.04236^{\star \star \star}$ & $0.7330^{\star \star \star}$ \\
\hline & $(0.2025)$ & $(0.2806)$ & (0.01469) & (0.2081) & $(0.2451)$ & (0.01338) & $(0.1802)$ \\
\hline \multirow[t]{2}{*}{ monthlywage } & $0.3309^{\star \star \star}$ & $0.4419^{\star \star \star}$ & $0.01636^{\star \star \star}$ & $0.3527^{\star \star \star}$ & $0.4427^{\star \star \star}$ & $0.01640^{\star \star \star}$ & $0.3533^{\star \star \star}$ \\
\hline & (0.03868) & (0.06620) & (0.002839) & $(0.05334)$ & $(0.06634)$ & $(0.002847)$ & (0.05344) \\
\hline \multirow[t]{2}{*}{ residence owned } & $0.5606^{\star \star \star}$ & $0.7076 \star \star$ & $0.02755^{\star \star}$ & $0.5593^{\star \star}$ & $0.6316^{\star * *}$ & $0.02447^{\star \star \star}$ & $0.4996^{\star \star *}$ \\
\hline & (0.1996) & $(0.2954)$ & (0.01243) & (0.2308) & (0.1573) & $(0.006827)$ & (0.1229) \\
\hline \multirow[t]{2}{*}{ financial help upon arrival } & $0.4153^{\star \star}$ & $0.5420^{\star \star}$ & $0.02121^{*}$ & $0.4279 * \star$ & $0.3543^{\star \star}$ & $0.01361^{\star \star}$ & $0.2808^{\star \star}$ \\
\hline & (0.1929) & $(0.2751)$ & (0.01156) & $(0.2146)$ & $(0.1647)$ & (0.006676) & (0.1295) \\
\hline \multirow[t]{2}{*}{ Duration of last migration (in months) } & $-0.01705^{\star \star \star}$ & $-0.02105^{\star \star \star}$ & $-7.796 e-04^{\star \star \star}$ & $-0.01680^{\star \star \star}$ & $-0.02010^{\star \star \star}$ & $-7.447 \mathrm{e}-04^{\star \star \star}$ & $-0.01604^{\star * *}$ \\
\hline & $(0.003870)$ & (0.006159) & $(2.415 e-04)$ & $(0.004908)$ & $(0.003558)$ & $(1.531 \mathrm{e}-04)$ & $(0.002817)$ \\
\hline Constant & $\begin{array}{l}0.8356 \\
(0.4037) \\
\end{array}$ & $\begin{array}{l}-0.7849 \\
(0.6488) \\
\end{array}$ & & & & & \\
\hline INTERACTIONS (illegal/demogr characteristics) & YES & YES & YES & YES & NO & NO & NO \\
\hline R-squared & 0.142 & & & & & & \\
\hline Pseudo R2 & & 0.334 & & & 0.327 & & \\
\hline sigma & & 2.9969 & & & 3.000 & & \\
\hline Observations & & 1,806 & 1,806 & 1,806 & 1,806 & 1,806 & 1,806 \\
\hline Log likelihood & & -4061.8 & -4061.8 & -4061.8 & -4063.96 & -4063.96 & -4063.96 \\
\hline
\end{tabular}

Robust standard errors in parentheses

*** $p<0.01$, ** $p<0.05$, * $p<0.1$ 


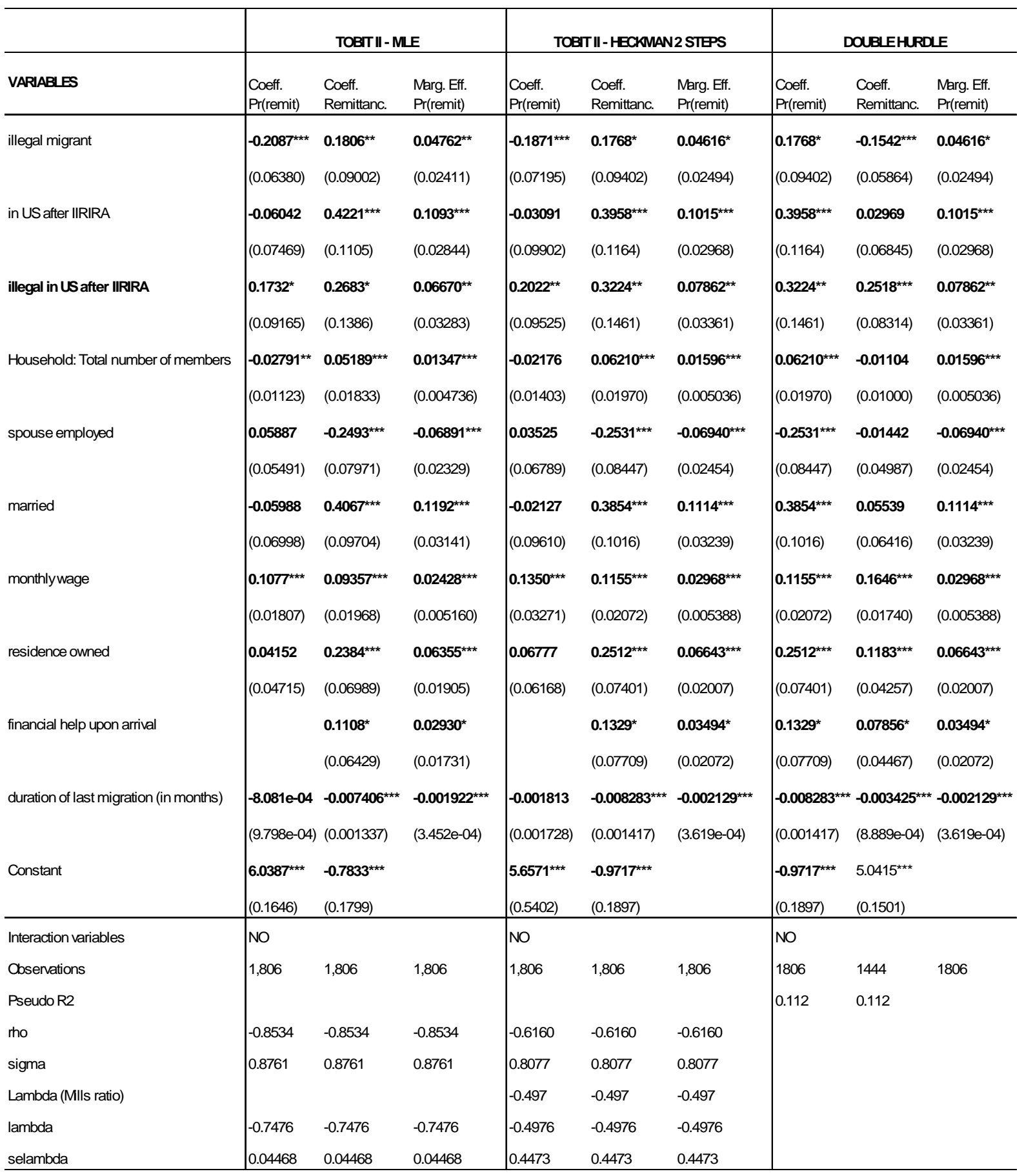

Standard errors in parentheses

*** $\mathrm{p}<0.01$, ** $\mathrm{p}<0.05$, * $p<0.1$ 